\title{
Genetic Variation Amongst and Within the Native Provenances of Pinus radiata D. Don in South-eastern Australia. 3. Molecular and Quantitative Structure
}

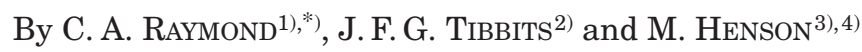

(Received $4^{\text {th }}$ August 2009)

\begin{abstract}
Patterns of differentiation between populations within a species can be examined using both molecular and quantitative data, with observed differences indicative of adaptation to local conditions. Pinus radiata D. Don (radiata pine) is a species of commercial importance in many countries but also listed as conservation dependent in its native range on the Californian coast and two off shore islands. This paper presents a comparative analysis of existing molecular data with new quantitative data from a large provenance/progeny trial in southeastern Australia.

Microsatellite data was reanalysed using a Bayesian model to test whether the a priori assumption of five natural occurrences was valid. With the validity of the geographic structure confirmed, two further approaches were used to examine genetic structure 1. a comparative study of $\mathrm{F}_{\mathrm{st}}$ and $\mathrm{Q}_{\mathrm{st}}$ estimates to investigate the role of drift and selection in shaping the differentiation between the populations for breeding traits and 2. population clustering based on both quantitative and molecular data.

Results strongly support the hypothesis that the island provenances of Pinus radiata are distinctly different to the mainland provenances. The molecular evidence also indicates the island provenances are different to each other. However, these differences were not apparent for the quantitative traits related to tree growth and form. The two island populations were however, strongly differentiated from each other for wood density and acoustic velocity. The patterns of phenotypic differentiation of the island provenances for these wood traits are both consistent with, and greater than, that observed for the molecular data, providing some evidence for directional selection on these traits. This study provides a background for the interpretation of molecular studies aimed at detecting molecular signatures of selection and associating genetic variation within genes with these traits.
\end{abstract}

Key words: Pinus radiata, provenances, Californian collection, $\mathrm{Q}_{\mathrm{st}}, \mathrm{F}_{\mathrm{st}}$, structure.

1) Centre for Plant Conservation Genetics, Southern Cross University, PO Box 157, Lismore NSW 2480 Australia.

2) Department of Primary Industries, Biosciences Research Division, Victorian AgriBiosciences Centre, 1 Park Drive, La Trobe University Research and Development Park, Bundoora, Victoria 3083, Australia

3) Forests NSW, PO Box J19, Coffs Harbour Jetty, NSW 2450 Australia.

$\left.{ }^{4}\right)$ Current address: Eucalyptus.Biz, Rosemead, Polesden Lane, Ripley, Surrey GU236DX, England.

*) Corresponding Author: Dr. CAROLYN RAYMond.

Phone +61 26620 3142, Fax +61 26622 2080. E-Mail: Carolyn. Raymond@scu.edu.au

\section{Introduction}

Quantitative and/or molecular differentiation (above or below a neutral rate) between populations within a species can imply adaptation to local conditions. Population structure and patterns of variation within a species can be examined using both molecular and quantitative data. Molecular markers, such as isozymes or microsatellites, are generally assumed to be neutral (McKay and Latta, 2002; Latta 2003) and not under direct selection. In contrast, quantitative traits, such as growth or tree form, may be subject to natural selection in native populations and to man-made selection in breeding programs.

One method for examining spatial differentiation is to calculate the proportion of total variance that occurs between populations: for molecular data this is labelled $F_{\text {st }}$ and the equivalent term for quantitative data is $Q_{s t}$ (MCKAY and LATTA, 2002). Significant differences between these two measures of spatial differentiation are interpretable as due to selection. In general the larger the difference between $F_{s t}$ and $Q_{s t}$ the stronger the degree of local adaptation implied in that trait, and hence, the degree of inferred selection. If $Q_{\mathrm{st}}$ is significantly greater than $\mathrm{F}_{\mathrm{st}}$ diversifying selection is implied whereas a significantly smaller $Q_{\text {st }}$ would imply stabilising selection (STEANE et al., 2006).

Pinus radiata D. Don (radiata pine) is an important commercial plantation species, especially in the southern hemisphere, where it is planted on over 3 million hectares and in many countries. However, the native range of radiata pine is very small and limited to the Californian coast and two off shore islands. So, although the species is widely used for commercial plantations, within its native range it is listed as conservation dependent (LR/cd) under the IUCN and is dependent on conservation efforts to prevent it becoming threatened with extinction.

The native distribution of radiata pine is disjunct and limited to three separate locations along the central California coast and two islands off the coast of Mexico (LiBBy, 1997). The three Californian mainland locations, Año Nuevo, Monterey and Cambria, form discrete provenances separated by a minimum of 80 kilometres. The two remaining provenances are located on Guadalupe and Cedros islands and geographically isolated from the mainland populations and from each other. The existence of these island provenances was known in 1876 but only since the 1950s has it become clear that both are varieties of $P$. radiata. For example, the Cedros Island population was previously assigned to $P$. muricata (Millar, 1986; BuRdon, BanNister et al., 1992). 
These island provenances are now designated as distinct varieties; $P$. radiata var. binata Engelmann for the Guadalupe population, and $P$. radiata var. cedrosensis (Howell) Silba for the Cedros island populations (MILLAR, 1986).

All five radiata pine provenances have clearly defined boundaries with very few outlying native trees (LIBBY, 1997). The geographic distribution of each provenance is closely linked to the band of summer sea fog that occurs along the coast due to moisture laden on-shore winds (LIBBY, 1997). However, the provenance locations do differ in climate (temperature and rainfall), elevation and soil type and therefore selective pressures would also be expected to differ. The central Californian provenance of Monterey occupies the largest area (3,800 ha), followed by the more southern of the Californian provenances, Cambria (900 ha) and then the more northern mainland provenance of Año Nuevo (450 ha) (ELDRIDGE, 1978). The two island provenances have limited distribution with only approximately 220 mature radiata pine trees on Guadalupe Island occurring along the top of a ridge and no regeneration occurring due to grazing by goats (ELDRIDGE, 1978). Two separate populations occur on Cedros Island, one along the central ridges of the island and the other $15 \mathrm{~km}$ away on ridges and cliffs at the northern end of the island (LIBBY, 1997).

Cedros Island was once linked to mainland Baja California and shares many of the same species of native plants and animals as the mainland sites (LIBBY, 1997). The origin of the Guadalupe provenance is less clear. Guadalupe is a volcanic island which appeared from the deep ocean floor about 7 million years ago (LIBBY, 1997). Relatively few species have colonised the island and $P$. radiata is presumed to have invaded the island some time in the relatively recent geological past. LIBBY (1997) speculates that the pines may have arrived as seeds in still-closed cones attached to floating logs which washed up on the island some time between one and four million years ago.

The genus Pinus is thought to have evolved in the mid-latitudes of Laurasia between 225 and $100 \mathrm{Ma}$ (million years ago) during or before the Cretaceous Period of the Mesozoic Era (LIBBY, 1997; Millar, 1997). No fossils representative of the closed cone pines (subsection Oocarpae), which includes $P$. radiata, $P$. muricata and $P$. attenuata, have been found in early deposits and this subsection appears to have been more recently derived from the subsections Ponderosae or Australes in the mountains of Mexico in the early to mid Miocene (25-15 Ma) (MILlaR, 1997). This area was part of an early Tertiary (65-34 Ma) refugium for pines and became an active centre for secondary radiation. The specific evolutionary history of $P$. radiata, interpreted for limited fossilised cones, suggests that Cedros provenance is probably the oldest and derives from an ancient mainland alliance (MORAN et al., 1988; Rogers, 2002). Cambria and Año Nuevo are considered the youngest populations, based on their larger cone size. Radiata pine fossils have been found over a wider area of California than the species currently occupies (LIBBY, 1997; ROGERS, 2002), suggesting that the current provenances are either remnants from a previously larger forest or, alternatively, that small discrete populations have existed throughout geological history, with the locations of these populations changing with time.

Variation between and within provenances of $P$. radia$t a$ has been subject to investigation and several seed collections have been undertaken across the native range. The most extensive was in 1978 (ELDRIDGE, 1978) and seed from this collection was used to establish a large number of provenance trials in several countries (see RAYMOND and HENSON, 2009). Within this collection, the mainland provenances were divided into a number of populations and individual tree seed collections conducted on varying numbers of parents per population. Individual tree identity was also maintained for the island collections. In 1980 these individual family seedlots were planted together in a large provenance/progeny trial in Australia which has been assessed for a range of quantitative traits up to the age of 26 years (see RAYMOND and Henson, 2009). Family seedlots from the island provenances were also planted in a separate trial which was assessed for a range of quantitative traits at age 24 years (RAYMOND et al., 2009).

In general, the results of the provenance variation studies are in agreement, with each of the mainland provenances having significant and overlapping patterns of variation while the island provenances are often distinct (BURDON, 1992; BURDON, GASKIN et al., 1992; BURDON and LOW, 1992; GARNIER-GÉRÉ et al., 1997; KINLOCH and LIBBY, 1997). Overall it appears that the patterns of variation between the natural provenances are multi-dimensional with resemblance between provenances strongly dependent on the traits selected. For example, Monterey is often intermediate in phenotype between Año Nuevo and Cambria, e.g. in monoterpene composition and in the persistence of juvenile characteristics, however, Año Nuevo is intermediate between Cambria and Monterey for various cone characteristics (Burdon, 1992). Año Nuevo and Monterey are most similar for resistance to needle-cast diseases such as Dothistroma needle blight (ADES and SIMPSON, 1991) and Diploidia-associated dieback (BURDON, 1992) and in resistance to Phytopthora cinnamomi (BUTCHER and STUKELY, 1997) however, Monterey appear less resistant to Endrocronartium harknessii (Western Gall rust) infection than both Año Nuevo and Cambria (KINLOCH and LIBBY, 1997). Wood properties, in contrast to many pine species, do vary significantly between the natural provenances. For example, the island provenances have an approximately $10 \%$ higher wood density in the first five rings from the pith than do the mainland provenances and, among the mainland provenances, Monterey and Año Nuevo have a higher average density than Cambria (BURDON and Low, 1992; RAYMOND et al., 2009).

Seed from this collection has also been assayed for isozyme variation (MORAN et al., 1988), and microsatellites were used (KARHU et al., 2006) to study variation amongst 20 year old trees in one of the provenance bulk seedlot trials (without family identity maintained). Similar to the quantitative studies, the molecular studies have indicated large, significant differences between the provenances, particularly between the island and mainland groups. The isozyme study (MoRAN et al., 1988) also indicated little variability between populations within 
each provenance. Importantly, no relationship was found between population census size and level of genetic diversity.

While the a priori assumption that the five natural occurrences are genetically distinct is likely to be reasonable, this geographic classification may not accurately reflect the true underlying genetic structure of $P$. radiata as drift may not have had long enough to act or significant gene flow, via pollen migration, may have continued to occur. Violation of the assumption that geographic origin is a strong surrogate for genetic group affiliation would undermine interpretation of both molecular and quantitative studies. To counter-act this potential problem the microsatellite data from KARHU et al. (2006) was reanalysed using the Bayesian models implemented in STRUCTURE (PRITCHARD et al., 2000). In this analysis we aim to estimate the number of genetic groupings $(K)$ and to determine if these correspond to the number of observed geographic populations.

Once the validity of the geographic structure was clarified, two different approaches were used to examine structure within Pinus radiata:

1) a comparative study of $F_{s t}$ and $Q_{s t}$ estimates to investigate the role of drift and selection in shaping the differentiation between the populations for breeding traits.

2) Population clustering based on both quantitative and molecular data

These two approaches were used as analyses of population structure using $\mathrm{F}_{\mathrm{st}}$ and $\mathrm{Q}_{\mathrm{st}}$ may provide conflicting results (McKAY and LATTA, 2002), and $\mathrm{Q}_{\text {st }}$ values may differ between different traits (LATTA, 2003). This dual approach is supported by a recent analysis by MILLER et $a l$. (2008) which indicated the potential for a strong correlation to occur between $Q_{s t}$ values and the $Q_{s t}-F_{s t}$ difference, with this being more problematic if quantitative traits exhibit large phenotypic variation. In the current study we use new quantitative data collected from the 1980 provenance/progeny trial planted at Batlow, NSW and previously published microsatellite marker data from a provenance trial from the same 1978 collection but planted in Canberra, ACT, and isozyme data from seeds of the same collection.

\section{Materials and Methods}

\section{Genetic material and field site}

Four hundred and sixty individual family seedlots from the 1978 seed collection (ELDRIDGE, 1978) were planted in 1980 with a local seed orchard control in a large provenance/progeny trial in Green Hills forest, south west of Tumut (latitude $35^{\circ} 17^{\prime}$, longitude $148^{\circ} 13^{\prime}$, altitude $302 \mathrm{~m}$ ) on the south western slopes of New South Wales. Full details of trial design and tree growth and form assessments are in RAYMOND and HENSON (2009) and wood density and stiffness assessments in RAYMOND et al. (2009). In summary, the trial was planted using an incomplete block design with 7 replicates and 4 tree row plots.

All trees were measured for total height in 1983 and 1988, diameter over bark at $1.3 \mathrm{~m}$ above ground (DBH) in 1988 and 2006 and in 2006 trees were also scored for straightness $(1=$ crooked to $6=$ straight), branch angle ( $1=$ steeper than $45^{\circ}$ to $3=$ less than $45^{\circ}$, tending to flat) and nodality ( 1 = uninodal, $2=$ low or uneven nodality, $3=$ moderately nodal and $4=$ highly multinodal). At age 26 years, a subset of trees was sampled for wood density (pith to bark in 5 ring increments) and standing tree acoustic velocity (RAYMOND et al., 2009). Population means and heritability for each growth and form trait are presented in Table 1 and wood density and acoustic velocity data is in Table 2.

Families from the island provenances were also established in 1982 in a separate trial in Buccleuch forest, northwest of Tumut. Thirty four families from Cedros provenance and 44 families from Guadalupe provenance were planted as single tree plots in a randomised complete block design. Full details of trial design and assessment are in RAYMOND et al. (2009). Data collected from both the Green Hills and Buccleuch trials were used to calculate between provenance $\mathrm{Q}_{\mathrm{ST}}$ values for a range of traits.

Table 1. - Population means for percentage survival (Surv) at age 26, height (Ht) at ages 3 and 8 years and diameter (DBH) at ages 8 and 26 years, stem straightness (STR), branch angle (BRA) and nodality (NOD). Data is for the Green Hills trial with the 5 provenances planted together. Heritability values for each trait are from RAYMOND and HENSON (2009).

\begin{tabular}{|l|c|c|c|c|c|c|c|c|c|}
\hline Provenance & Pop. & Surv & Ht 3 & Ht 8 & DBH 8 & DBH 26 & STR & BRA & NOD \\
\hline Año Nuevo & $01-1$ & 57 & 8.34 & 13.39 & 11.36 & 29.95 & 3.58 & 2.16 & 2.58 \\
& $01-2$ & 59 & 8.44 & 13.35 & 11.36 & 30.31 & 3.71 & 2.09 & 2.65 \\
& $01-3$ & 53 & 8.21 & 13.28 & 11.37 & 30.71 & 3.77 & 2.13 & 2.53 \\
& $01-4$ & 58 & 8.30 & 13.70 & 11.72 & 31.96 & 3.81 & 2.18 & 2.53 \\
\hline Monterey & $02-1$ & 50 & 7.99 & 14.26 & 11.42 & 30.02 & 3.77 & 2.00 & 2.66 \\
& $02-2$ & 53 & 8.14 & 14.27 & 11.60 & 29.39 & 3.57 & 1.99 & 2.48 \\
& $02-3$ & 56 & 8.16 & 14.33 & 11.78 & 30.32 & 3.77 & 2.04 & 2.59 \\
& $02-4$ & 55 & 8.26 & 14.64 & 11.73 & 29.94 & 3.62 & 2.05 & 2.53 \\
& $02-5$ & 54 & 8.09 & 14.34 & 11.63 & 29.89 & 3.54 & 1.94 & 2.52 \\
& $02-6$ & 48 & 8.09 & 14.14 & 11.47 & 29.51 & 3.53 & 2.05 & 2.50 \\
\hline Cambria & $03-1$ & 24 & 7.63 & 13.99 & 10.91 & 22.73 & 3.24 & 1.82 & 2.25 \\
& $03-2$ & 40 & 7.88 & 13.84 & 11.32 & 26.09 & 3.51 & 1.87 & 2.46 \\
& $03-3$ & 40 & 7.83 & 13.76 & 11.15 & 24.93 & 3.44 & 1.92 & 2.50 \\
\hline Guadalupe & 14 & 12 & 6.19 & 10.90 & 6.83 & 18.77 & 3.61 & 1.81 & 2.35 \\
Cedros & 15 & 4 & 4.03 & 6.96 & 4.75 & 17.37 & 3.28 & 2.07 & 2.22 \\
Control & & 77 & 8.86 & 14.82 & 12.98 & 37.13 & 4.73 & 2.39 & 3.24 \\
\hline Heritability & & & 0.31 & 0.22 & 0.27 & 0.18 & 0.19 & 0.19 & 0.27 \\
\hline
\end{tabular}


Table 2. - Population means for extracted wood density for each 5 ring segment from the bark (A) to the pith (E) and standing tree acoustic velocity at 26 years for each population in each of the mainland provenance growing at the Green Hills site. Data for the island provenances is from the Buccleuch site. Heritability values for each trait are from RAYMOND et al. (2009).

\begin{tabular}{|l|c|c|c|c|c|c|c|}
\hline Provenance & Pop. & A & B & C & D & E & $\begin{array}{c}\text { Acoustic } \\
\text { Velocity }\end{array}$ \\
\hline Año Nuevo & $01-1$ & 447 & 456 & 428 & 380 & 344 & 3.91 \\
& $01-2$ & 440 & 449 & 422 & 381 & 349 & 3.87 \\
& $01-3$ & 430 & 440 & 418 & 369 & 337 & 3.84 \\
& $01-4$ & 430 & 438 & 416 & 379 & 347 & 3.89 \\
\hline Monterey & $02-1$ & 444 & 446 & 441 & 382 & 350 & 4.04 \\
& $02-2$ & 457 & 451 & 441 & 373 & 344 & 4.10 \\
& $02-3$ & 449 & 447 & 437 & 381 & 343 & 4.03 \\
& $02-4$ & 450 & 451 & 448 & 383 & 342 & 4.13 \\
& $02-5$ & 460 & 456 & 445 & 385 & 348 & 4.07 \\
\hline Cambria & $02-6$ & 455 & 456 & 449 & 390 & 348 & 4.06 \\
\hline Heritability & $03-1$ & 453 & 452 & 433 & 365 & 327 & 3.81 \\
\hline Guadalupe* & $03-2$ & 437 & 455 & 447 & 368 & 336 & 4.04 \\
Cedros* & $03-3$ & 451 & 461 & 446 & 380 & 341 & 4.12 \\
\hline Heritability* & 14 & 0.51 & 0.47 & 0.43 & 0.36 & 0.16 & 0.28 \\
\hline
\end{tabular}

* From the Buccleuch trial containing only the island provenances.

\section{Validation of geographic provenances}

The microsatellite data from KARHU et al. (2006) was reanalysed using the Bayesian models implemented in STRUCTURE (PRITCHARD et al., 2000) to estimate the number of genetic groupings $(K)$. Unlike prior analyses of this data, individual trees are not assigned to populations a priori and the optimal number of genetic groups $(K)$ is estimated based purely on co-ancestory.

As the characteristics of the input data set have been shown to have significant effects on the power and reliability when estimating $K$ (PRITCHARD et al., 2000; ROSENBERG et al., 2001; ROSENBERG et al., 2003; ROSENBERG, 2005; RosenberG et al., 2005) some discussion of the input data set is warranted. Missing data do not appear to significantly affect the result of clustering, if the misses are not too frequent or systematic. The average amount of missing data in the data from KARHU et al. (2006) across all loci is $8.3 \%$, with the maximum missing data being $19.2 \%$ for locus Pr-048 and the lowest $1.3 \%$ for Pr-001 so missing data are unlikely to cause any major anomalies in this re-analysis. Inbreeding and the presence of genotyping errors (including incorrectly assigned null alleles) can lead to overestimation of $K$ especially for models that allow admixture within individuals and also assume correlated allele frequencies between clusters (PRITCHARD et al., 2002). The Cedros Island population shows some evidence of long term inbreeding (VoGL et al., 2002). Otherwise, levels of inbreeding are low in $P$. radiata and it can be considered to be an outcrossing species (VoGL et al., 2002). The data set has three loci (Pr161, Pr060-2 and Pr011) for which null alleles were inferred with frequencies greater than $10 \%$ over all populations. All other loci had null allele frequencies of less than $5 \%$. The presence of null alleles was confirmed at these loci by genotyping haploid megagametophyte tissues (KARHU et al., 2006); however, the loci with large numbers of null alleles may still be those with a significant number of genotyping errors.
Separate simulations across a range of $K(K=1$ to $K=10)$ indicated that exclusion of the loci Pr060-2, Pr011, with their high level of inferred null alleles, gave more stable simulations [smaller variance in $\ln \mathrm{P}(\mathrm{D})$ between runs] and individual assignments that were less symmetric at higher $K$. All subsequent analyses were conducted without these markers included.

Simulations for $K$ ranging from 1 to 10 were run assuming no individual admixture and independent allele frequencies between clusters (NA/Ind), admixture with independent allele frequencies (A/Ind) and admixture with correlated allele frequencies $(\mathrm{A} / \mathrm{C})$. At least five simulations were conducted for each $K$ under each set of assumptions. Run lengths were generally 200000 iterations as a burn in followed by 500000 iterations used for estimation of $\log \mathrm{P}(K / X)$. Shorter simulations led to very high variance in estimates of $\log \mathrm{P}(K / X)$ at $K>5$. For $K=5$ and 6 for the model A/C runs were made with 200000 burn in and 3000000 MCMC in an attempt to better estimate the posterior probabilities. Analysis otherwise generally follows the procedures and recommendations outlined in PRITCHARD et al. (2000) and RosEnBERG et al. (2001). The number of iterations gave approximate stationarity for the estimated parameters within a simulation, although with $K>5$ there was increased variance between estimates of $\log \mathrm{P}(K / X)$. In general all runs at the same $K$ had a similar, and not significantly different, likelihood of being correct (tested by likelihood ratio test) and therefore all simulation results at each $K$ with the same likelihood were averaged for use in calculations of estimated posterior probabilities.

\section{Data analysis and $Q_{S T}$ calculation}

Pairwise between-provenance $\mathrm{Q}_{\mathrm{ST}}$ estimates (and their standard errors) for all provenance combinations were calculated with the data from the Green Hills trial using ASREML (GILMOUR et al., 2002) and fitting a 
model with fixed replicate effect and random provenance and family effects as:

$$
Q S T=\sigma_{\text {provenance }}^{2} /\left(\sigma_{\text {provenance }}^{2}+2 \sigma_{\text {additive }}^{2}\right)
$$

where $\sigma_{\text {provenance }}^{2}$ is the provenance component of variance and $\sigma_{\text {additive is the additive (within provenance) }}^{2}$ variance which, assuming a half sib relationship, is equal to $4 *$ family variance component. Within-provenance $\mathrm{Q}_{\mathrm{ST}}$ estimates (and their standard errors) were calculated using a similar model, fitting location within provenance and family as random terms.

\section{Population cluster analysis}

\section{1) Quantitative data}

Best linear unbiased predictors (BLUPs) for provenances and population means were estimated by fitting the following model:

$$
\mathrm{Y}=\mathrm{mu}+\mathrm{Rep}+\text { Rep.ICB }+ \text { Population + error }
$$

with Rep treated as a fixed effect and ICB and Population as random. The population BLUPS for growth, tree form, wood density and acoustic velocity plus survival at Green Hills were used as input data to form a similarity matrix for the mainland provenances. The poor survival of the island provenances in the Green Hills trial at age 26 years (less than 15\%) prevented a comparison of all provenances across all traits. However, the early growth data (to age 8 years) was considered valid as survival of all provenances except Cedros was above 90\% (RAYMOND and Henson, 2009). A separate similarity matrix was formed using height and diameter growth to age 8 years to allow for comparison amongst the provenances and with the control seedlot. Clustering was done using the single link method with results presented as dendrograms.

\section{2) Molecular data}

Pairwise between-provenance $\mathrm{F}_{\mathrm{ST}}$ estimates (Table 3) were sourced from two previously published studies where $\mathrm{F}_{\mathrm{ST}}$ estimates are based on different molecular markers. The KARHU et al. (2006) study used 19 microsatellite loci to estimate $\mathrm{F}_{\mathrm{ST}}$ and MORAN et al. (1988) used 5 isozyme loci.

Table 3. - Pairwise estimates of genetic differentiation $\left(\mathrm{F}_{\mathrm{ST}}\right.$ and $\left.\mathrm{Q}_{\mathrm{ST}}\right)$ between provenances of $P$. radiata based on 5 isozyme loci (from MoRAN et al., 1988), 19 microsatellite loci (from KARHU et al., 2006) and $\mathrm{Q}_{\mathrm{ST}}$ calculated for a range of quantitative traits from data in RAYMOND and HENSON, 2009; RAYMOND et al., 2009). Guadalupe and Cedros are the two island provenances. Highlighted $\mathrm{Q}_{\mathrm{ST}}$ values are greater than their standard error.

\begin{tabular}{|l|c|c|c|c|c|}
\hline & $\begin{array}{c}\text { Año Nuevo } \\
\text { Monterey }\end{array}$ & $\begin{array}{c}\text { Año Nuevo } \\
\text { Cambria }\end{array}$ & $\begin{array}{c}\text { Monterey } \\
\text { Cambria }\end{array}$ & $\begin{array}{c}\text { Año Nuevo } \\
\text { Guadalupe }\end{array}$ & $\begin{array}{c}\text { Año Nuevo } \\
\text { Cedros }\end{array}$ \\
\hline Isozymes & 0.023 & 0.052 & 0.030 & 0.089 & 0.223 \\
Microsatellites & 0.048 & 0.070 & 0.027 & 0.172 & 0.193 \\
Height age 3 & 0.009 & 0.061 & 0.025 & 0.508 & 0.826 \\
Height age 8 & 0.044 & 0.010 & 0.010 & 0.225 & 0.706 \\
Diameter age 8 & 0.002 & 0.003 & 0.015 & 0.656 & 0.820 \\
Diameter age 26 & 0.005 & 0.340 & 0.233 & 0.737 & 0.740 \\
Straightness & 0 & 0.046 & 0.027 & 0 & 0 \\
Branch angle & 0.040 & 0.131 & 0.062 & 0.167 & 0 \\
Nodality & 0 & 0.022 & 0.019 & 0.018 & 0 \\
Density A & 0 & 0.002 & 0.015 & & \\
Density B & 0.001 & 0 & 0 & & \\
Density C & 0.006 & 0 & 0 & & \\
Density D & 0.011 & 0.032 & 0.085 & & \\
Density E & 0.059 & 0 & $\#$ & & \\
AcousticVelocity & 0.005 & 0 & 0 & & \\
\hline
\end{tabular}

\begin{tabular}{|l|c|c|c|c|c|}
\hline & $\begin{array}{c}\text { Monterey } \\
\text { Guadalupe }\end{array}$ & $\begin{array}{c}\text { Monterey } \\
\text { Cedros }\end{array}$ & $\begin{array}{c}\text { Cambria } \\
\text { Guadalupe }\end{array}$ & $\begin{array}{c}\text { Cambria } \\
\text { Cedros }\end{array}$ & $\begin{array}{c}\text { Guadalupe } \\
\text { Cedros }\end{array}$ \\
\hline Isozymes & 0.087 & 0.169 & 0.071 & 0.163 & 0.193 \\
Microsatellites & 0.175 & 0.178 & 0.192 & 0.204 & 0.175 \\
Height age 3 & 0.499 & 0.837 & 0.428 & 0.828 & 0.547 \\
Height age 8 & 0.361 & 0.753 & 0.263 & 0.703 & 0.516 \\
Diameter age 8 & 0.668 & 0.821 & 0.673 & 0.845 & 0.259 \\
Diameter age 26 & 0.630 & 0.650 & 0.382 & 0.360 & 0 \\
Straightness & 0 & 0 & 0 & 0 & 0 \\
Branch angle & 0.118 & 0 & 0 & 0 & 0 \\
Nodality & 0.018 & 0 & 0 & 0 & 0 \\
Density A & & & & & 0.440 \\
Density B & & & & & 0.303 \\
Density C & & & & & 0.032 \\
Density D & & & & & \\
Density E & & & & & 0.015 \\
AcousticVelocity & & & & & 0.208 \\
\hline
\end{tabular}

\# Heritability for this trait is zero in one provenance so $Q_{\mathrm{ST}}$ value not calculated. 


\section{Results}

In all STRUCTURE models the highest posterior probabilities were assigned to $K$ of 5 or 6 . In all models the best predicted genetic clusters were congruent with the geographic origin indicating that geographic origin serves as a reasonable surrogate for estimating genetic group affiliation. The most mixed population appears to be Monterey and the least mixed and best identified clusters were the island populations. Overall the models with $\mathrm{A} /$ Ind fitted the data better for the same $K$ over either models NA/Ind or A/C. For A/Ind models the most probable estimate for $K$ was $6[\mathrm{P}(\mathrm{X} / \mathrm{K}=6 ; 100 \%)]$. For A/C models both $K=5$ and $K=6$ returned estimated posterior probabilities appreciably greater than zero $[\mathrm{P}(\mathrm{X} / \mathrm{K}=5 ; 81 \%, \mathrm{P}(\mathrm{X} / \mathrm{K}=6 ; 19 \%)]$. The variance in run results at these two $K$ for the $\mathrm{A} / \mathrm{C}$ model indicated that stationarity had not been reached for 500000 MCMC. Extra simulations with 3 million MCMC for $K$ of 5 and 6 gave the same results as the averaging across multiple shorter runs. For NA/Ind and A/Ind runs with $K=5$, a non-geographically defined cluster was observed prior to the separation of the geographically expected clusters that correspond to Monterey and Cambria occurrences (light blue in Figure 1). The lack of fully assigned individuals in the non-geographically defined cluster and the different order of cluster separation between models indicated that this cluster may represent an artefact arising from inference of null alleles or other potentially structured genotyping errors within the data set. Overall, geographic origin appeared to serves as a reasonable surrogate for estimating genetic group affiliation.

Pairwise provenance values for $\mathrm{F}_{\mathrm{ST}}$ and $\mathrm{Q}_{\mathrm{ST}}$ (Table 3) indicated that the two different types of molecular markers produced similar $\mathrm{F}_{\mathrm{ST}}$ values for most comparisons. However, large differences were apparent between the $F_{S T}$ and $Q_{S T}$ values for some provenance comparisons, particularly those involving the island provenances. Comparisons amongst the mainland provenances yielded very different results to comparisons between the mainland and the islands. Almost no difference was detected between Año Nuevo and Monterey, with all values for $\mathrm{F}_{\mathrm{ST}}$ and $\mathrm{Q}_{\mathrm{ST}}$ being below 0.06. In contrast, the island provenances were distinctly different to all the mainland provenances, with $\mathrm{F}_{\mathrm{ST}}$ values ranging 0.07 to 0.22 and $\mathrm{Q}_{\mathrm{ST}}$ from 0 to 0.84 . The island provenances were also different to each other, with $\mathrm{Q}_{\mathrm{ST}}$ values ranging from 0 for stem form traits to $>0.5$ for height growth at ages 3 and 8 years.
Amongst the mainland provenances an age related trend was apparent for $\mathrm{Q}_{\mathrm{ST}}$ values of growth traits in comparisons between Cambria with Año Nuevo and Monterey. For comparisons between all three mainland provenances, the $\mathrm{Q}_{\mathrm{ST}}$ for growth up to age 8 were similar to, or lower, than the $\mathrm{F}_{\mathrm{ST}}$ for either isozymes or microsatellites (Table 3), indicating either little selection or that weak purifying or balancing selection was slowing the divergence of phenotype between populations. However, at age 26 the $\mathrm{Q}_{\mathrm{ST}}$ for diameter increased dramatically for comparisons between Cambria and the other two provenances. While it is possible that this indicated directional selection it may have also arisen from inflation of the $\mathrm{Q}_{\mathrm{ST}}$ values by between family competition effects within the field trial with the slower growing Cambria trees being out-competed (see Table 1 for mean values).

In the Green Hills trial, the island provenances also suffered from major competition effects after age 8 with the number of surviving trees rapidly declining until less than $15 \%$ are alive at age 26 years (Table 1 ). $\mathrm{Q}_{\mathrm{ST}}$ values calculated for the age 26 data for the island provenances were also doubtful as the remaining sample size within the island provenances was too small to be truly representative. However, $Q_{\mathrm{ST}}$ the values for early growth were better supported and indicated that, at ages 3 and 8 years, $\mathrm{Q}_{\mathrm{ST}}$ values were much larger than the $\mathrm{F}_{\mathrm{ST}}$ values (Table 3). This may indicate that directional selection is driving differentiation in growth traits faster than the underlying differentiation is occurring. The difference between the two island provenances was also large, and often larger than the difference between the islands and the mainland provenances, particularly for height growth. The poor survival of the island provenances in the Green Hills trial made it impossible to screen these provenances for wood quality and therefore $\mathrm{Q}_{\mathrm{ST}}$ comparisons for these traits were not calculated.

Within the mainland provenances, little differentiation between populations was apparent, either for the $\mathrm{F}_{\mathrm{ST}}$ from isozymes or the $\mathrm{Q}_{\mathrm{ST}}$ values for tree growth and form traits (Table 4). For Año Nuevo and Monterey the $\mathrm{Q}_{\mathrm{ST}}$ values were similar to, or lower than the $\mathrm{F}_{\mathrm{ST}}$ values, for most traits, again indicating selection slowing phenotypic divergence relative to molecular divergence. Within Cambria, the $\mathrm{F}_{\mathrm{ST}}$ value was much higher than most of the $\mathrm{Q}_{\mathrm{ST}}$ values; the only exceptions being for diameter and nodality at age 26 years and density in the inner most segment.

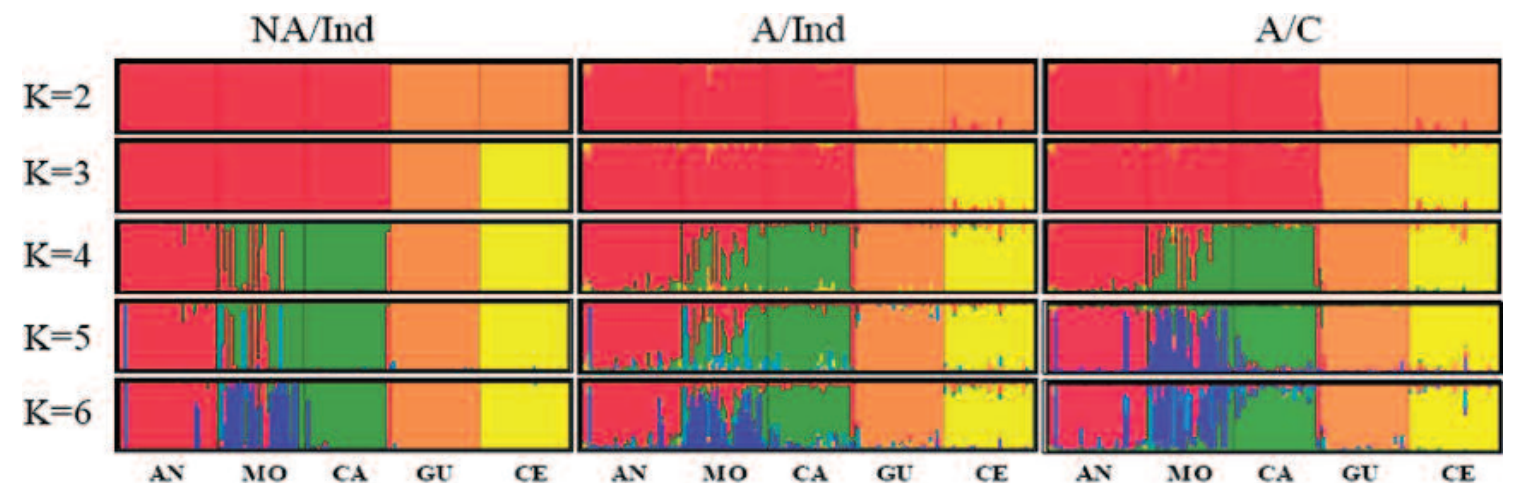

Figure 1. - Population ancestry assignments for a $\mathrm{K}=2$ to 6 model from STRUCTURE analysis of the microsatellite data from KARHU et al. (2006). 
The provenance clustering diagrams for isozymes (Figure 2), microsatellite data (Figure 3) and early growth quantitative traits (Figure 4) indicated the island provenances to be distinctly different to all mainland provenances for all data sets. No differences were apparent amongst the mainland provenances for the early growth data (Figure 4), however, for the molecular data the allegiances amongst the mainland provenances appeared to differ, with KARHU et al. (2006) analysis of the microsatellite data indicating that Monterey and Cambria were the closest pair, whilst the isozymes and quantitative data indicate that Monterey was closer to Año Nuevo. The re-analysis of the microsatellite data (Figure 5) indicated that Monterey is the most mixed provenance, with individuals having allegiance to both Cambria or Año Nuevo to be found. While this mixing may be the consequence of continued pollen flow or from incomplete drift (or both), the presence of ancestry from all three genetic groupings in Monterey may explain why the molecular studies differ in their grouping of the mainland populations.

Table 4. - Between populations within provenance estimates of genetic differentiation $\left(\mathrm{Q}_{\mathrm{ST}}\right)$ in $P$. radiata calculated for a range of quantitative traits from data in RAYMOND and HENSON, 2008). Highlighted $Q_{\mathrm{ST}}$ values are greater than their standard error.

\begin{tabular}{|l|c|c|c|}
\hline & Año Nuevo & Monterey & Cambria \\
\hline Isozymes\# & 0.022 & 0.017 & 0.021 \\
Height age 3 & 0 & 0.002 & 0.003 \\
Height age 8 & 0 & 0 & 0 \\
Diameter age 8 & 0 & 0 & 0.004 \\
Diameter age 26 & 0.021 & 0 & 0.085 \\
Straightness & 0.020 & 0.011 & 0.005 \\
Branch angle & 0 & 0 & 0 \\
Nodality & 0 & 0.006 & 0.079 \\
Density A & 0 & 0 & 0.06 \\
Density B & 0 & 0 & 0.05 \\
Density C & 0 & 0 & 0 \\
Density D & 0.09 & 0 & 0 \\
Density E & 0.08 & 0 & 0.22 \\
AcousticVelocity & 0.18 & 0.01 & 0.02 \\
\hline
\end{tabular}

\# Estimated proportion of gene differentiation between ecological stands from MORAN et al. (1988).

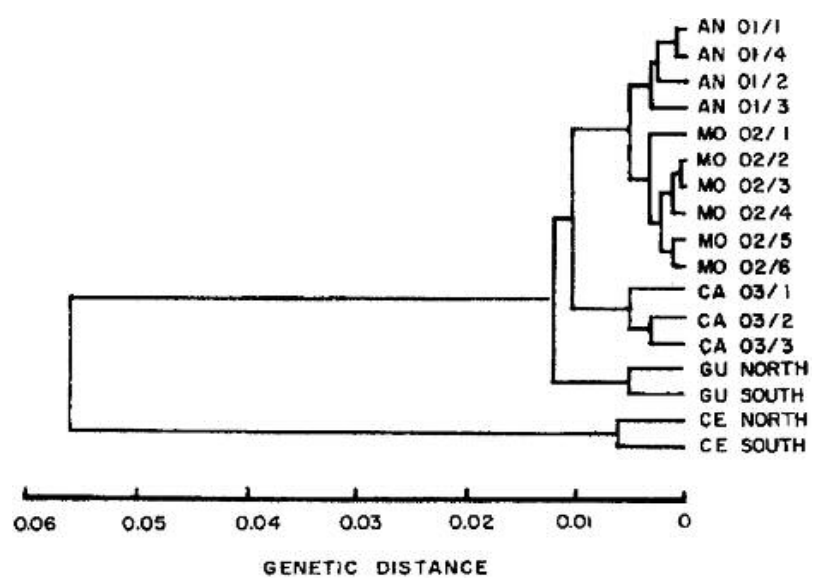

Figure 2. - Clustering dendrogram for unweighted pair group analysis based on Nei's genetic distance and using isozyme data from native provenances (from MoRAN et al., 1988). AN = Año Nuevo, $\mathrm{MO}=$ Monterey, $\mathrm{CA}=$ Cambria, $\mathrm{GU}=$ Guadalupe , $\mathrm{CE}=$ Cedros.

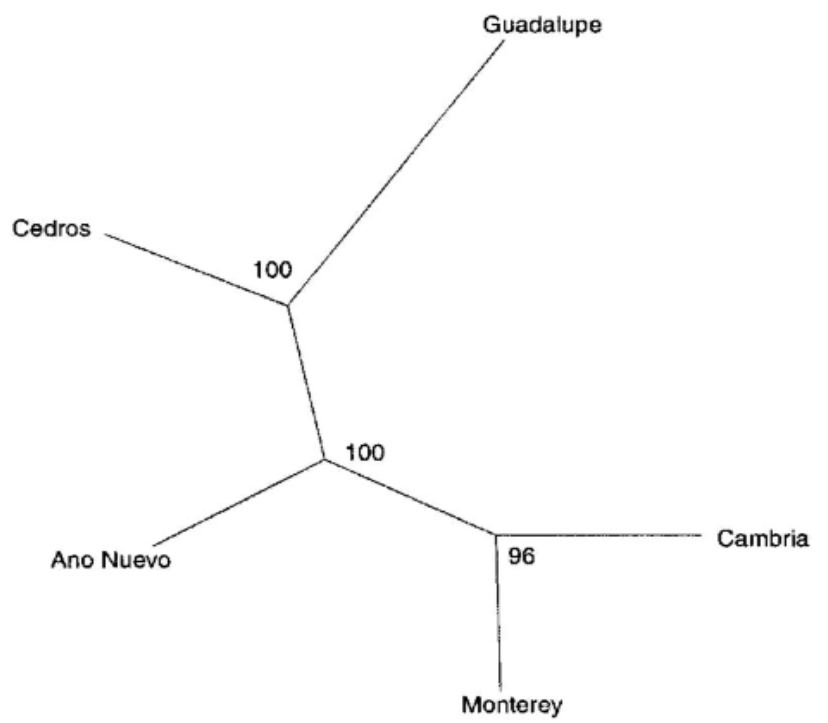

Figure 3. - UPGMA boot strap concensus tree based on Nei's genetic distance and using microsatellite markers from native provenances (from KARHU et al., 2006). Percentages at nodes indicate proportion of bootstrap replications in which the figured grouping appeared.

Within the mainland provenances, the clustering of the populations differed between the isozyme data (Figure 2) and the quantitative data at age 26 years (Figure 5). For both data sets Cambria is identified as being distinctly different to the other two provenances, with 03-1 (Pico Creek) being the most unrelated, especially for the quantitative data. Within Monterey, all populations appeared closely related for both the isozyme and quantitative data sets with $02-5$ and $02-6$ being the most closely related populations in both data sets. Interestingly, Figure 4 also indicated that, based on the early growth data, the local control seedlot is distinctly different to all of the mainland provenances. This difference clearly demonstrated the effectiveness of the adaptation of the landrace material and its subsequent selection for performance in the Australian environment. The affiliation of the landrace material was unclear and the only viable means to determination its origins are molecular approaches. Based on the isozyme work the origin of the local Australian landrace is currently believed to be sourced from Monterey and Año Nuevo (MoRAN and BELL, 1987).

Within Año Nuevo there are major differences in the clustering of populations. The isozyme and early growth data indicated that all the Año Nuevo populations cluster together, separated from the other mainland provenances. However, for the age 26 year data both 01-3 (inland south Swanston) and 01-4 (Inland northern) clustered with the Monterey populations. At this stage no molecular studies have sufficient data to investigate sub-provenance genetic structure in an unbiased manner and therefore it remains to be seen if there is true genetic differentiation at the sub-provenance level or not.

\section{Discussion}

Both the molecular and quantitative data support the hypothesis that the native provenances of Pinus radiata 


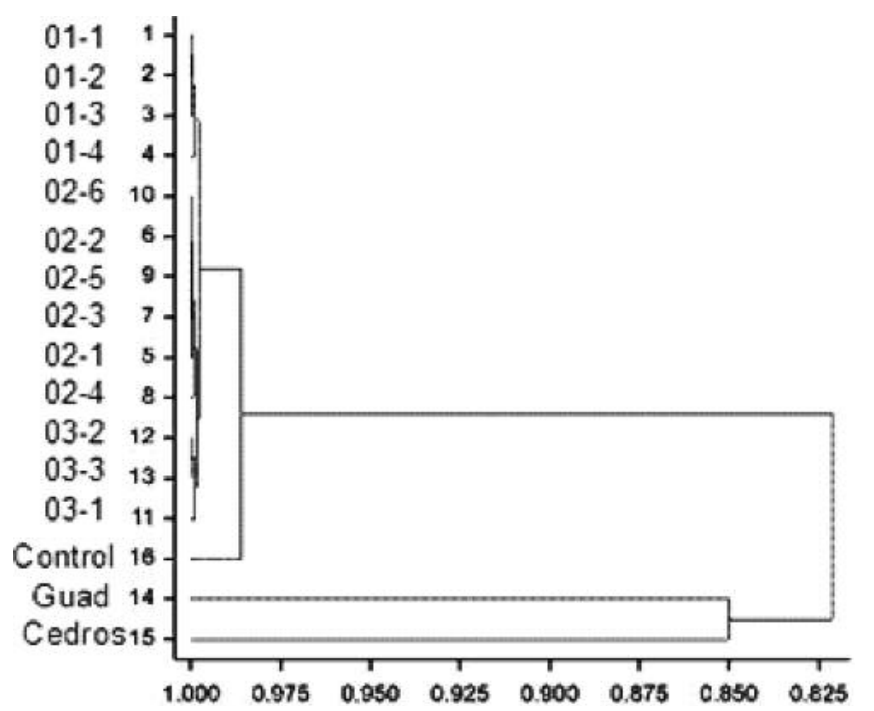

Figure 4. - Clustering dendrogram for height and diameter growth to age 8 for all provenances and populations plus the local seed orchard control. Clusters calculated using the single link method. $01=$ Año Nuevo, $02=$ Monterey, $03=$ Cambria Control $=$ seed orchard control, Guad $=$ Guadalupe, Cedros $=$ Cedros.

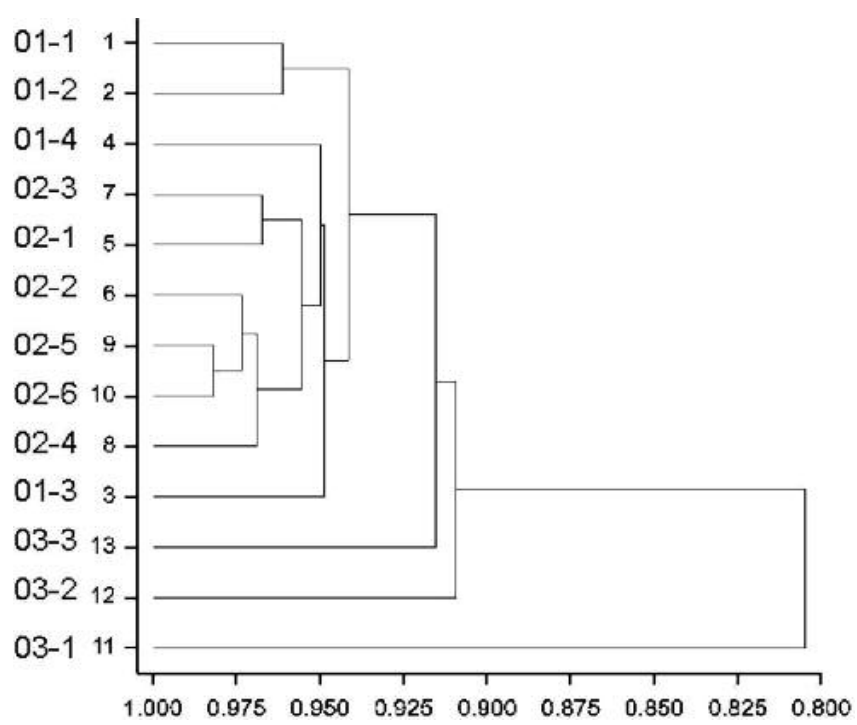

Figure 5. - Clustering dendrogram for all traits at age 26 years old for mainland provenances and populations. Clusters calculated using the single link method. 01 = Año Nuevo, 02 = Monterey, 03 = Cambria

form two groups, with the island provenances being distinctly different to the mainland provenances. Based on the molecular data the island provenances are also very different to each other. These differences were not apparent for tree growth and form traits where the island provenances are indistinguishable except for early height, where very strong differentiation is apparent (Table 1). The two island populations are however, strongly differentiated from each other for the wood properties; wood density and acoustic velocity (Table 2) and display different patterns of change in density from pith to bark (RAYMOND et al., 2009). The patterns of phenotypic differentiation of the island provenances for these wood traits are consistent as well as being greater than observed for the molecular data, indicating the pos- sibility of directional selection. This differentiation at both the molecular level and phenotypic level is not surprising given the predicted long term isolation of the island provenances from the mainland and also their isolation from one another. The possibility for selection to be driving differentiation for the growth and wood property traits between the islands and the mainland (and between each other) is also a reasonable proposition as the provenances on both islands occur in distinctly different environments.

Based on fossil remains and inferred evolutionary history, Cedros is believed to be the oldest provenance deriving from an ancient more southerly located mainland alliance. The isozyme and microsatellite data (MORAN et al., 1988; KARHU et al., 2006) support this assertion with Cedros always clustering as the most distant of the provenances, and being quite distinct to the other populations.

The origin of the Guadalupe provenance is also of interest as this location is a volcanic island that has never had any connection to the mainland. The isozyme analysis of MORAN et al. (1988) suggested the Guadalupe provenance has close genetic similarity to the mainland provenances, and the level of genetic diversity is consistent with the recent colonisation of the island by a number of individuals. This contrasts with the microsatellite data of KARHU et al. (2006) where Guadalupe is the most distinct of the provenances. The quantitative data also suggests that Guadalupe is quite distinct from all mainland provenances.

Given their geographic proximity, the mainland provenances and populations could be considered to meet the assumptions of drift-migration equilibrium (MERILÄ and CRNOKRAK, 2001). Hence comparison of results within and between these populations is of interest. Two of the provenances appear almost identical, whilst the third (Cambria) diverges. The similarity of Monterey and Año Nuevo provenances for both $\mathrm{Q}_{\mathrm{ST}}$ and $\mathrm{F}_{\mathrm{ST}}$ values, and the lack of large differences between populations within these provenances indicate that the degree of differentiation is low, and is similar for both the molecular and quantitative traits. This is somewhat surprising as it indicates a lack of directional natural selection acting on the tree growth, wood density and stiffness (measured using the surrogate of acoustic velocity) quantitative traits. As the resolution of these studies is at the provenance level it may still be possible that selection is acting within provenances in response to the different clines in climate and soil types within these two provenances but this differentiation was not detected. Geographically Monterey and Año Nuevo provenances are the closest together and gene flow between and within provenances may still be occurring.

The third provenance, Cambria, appears to be more distinct with both the $\mathrm{F}_{\mathrm{ST}}$ and, particularly, the $\mathrm{Q}_{\mathrm{ST}}$ values for diameter at age 26 years being larger. Again however, there is little support for directional selection force operating as the $\mathrm{F}_{\mathrm{ST}}$ and $\mathrm{Q}_{\mathrm{ST}}$ estimates are very similar. Interestingly, there is less differentiation in $\mathrm{Q}_{\mathrm{ST}}$ compared to $\mathrm{F}_{\mathrm{ST}}$ for the wood property traits among the mainland provenances. This may indicate that there is selection acting to constrain differentiation between these populations. 
The cluster analysis of the early growth data indicated that the local control seedlot is distinct from the mainland populations. It also had the highest survival and best growth (Table 1). This seedlot was collected from a seed orchard established using plantation selected plus trees in Australia (JoHnson et al., 1997). The origin of this local Australian population is believed to be Monterey and Año Nuevo (MoRAN and BELL, 1987). Yet, the cluster analysis indicates that the control appears different to all three of the mainland provenances. RAYMOND and Henson (2009) discuss possible reasons for the superiority of the Australian seedlot including natural selection to the local environment, lack of "neighbourhood inbreeding" effects present in the native stands and heterosis from crosses between the Monterey and Año Nuevo progenitors. Inbreeding was discarded as a possible reason due to the large population size of these native provenances, the fact that the species is wind pollination and the published low estimate for the average inbreeding coefficient within these populations (see Table 5). For the heterosis theory to have merit, these two provenances must differ is some essential way. Yet both the $\mathrm{Q}_{\mathrm{ST}}$ and $\mathrm{F}_{\mathrm{ST}}$ values, plus all the cluster analyses, appear to indicate that this is not the case, with these two provenances appearing to be almost identical. Which leaves the first option, of natural and artificial selection to the local environment, as the only viable explanation for the superiority of the local seedlot.

A couple of issues relevant to the comparison between $\mathrm{Q}_{\mathrm{ST}}$ and $\mathrm{F}_{\mathrm{ST}}$ values also need to be raised. The first is that most published estimates for both $\mathrm{Q}_{\mathrm{ST}}$ and $\mathrm{F}_{\mathrm{ST}}$ are point estimates, in that they are done at a single point in time. As a field trial ages, the patterns of spatial autocorrelation alter as the level of between-tree competition increases. This leads initially to increasing suppression of neighbouring trees and then to mortality in suppressed trees. It is worth asking what effect does this have on $\mathrm{Q}_{\mathrm{ST}}$ ? Do we expect the same estimates if we sample the same populations at different stages in their development, for example as seeds and adult trees? The changes in $\mathrm{Q}_{\mathrm{ST}}$ we observed between different ages within this trial indicate that these estimates are not static. We proposed that these changes are being driven by the confounded temporal stand-based changes such as increasing suppression of the Cambria families. Such temporal changes are also observed in the estimates of heritability for many of the traits which provided some support to this proposition. We can similarly ask would $\mathrm{F}_{\mathrm{ST}}$ be expected to change with developmental stage? While the answer here is maybe a more definite "no", as the molecular markers are assumed to be neutral, it may be worth pondering if inbreeding levels are changing due to selection against inbred individuals during stand development. The inbreeding levels within the mainland populations are estimated to be very low (Table 5) and while inbred individuals from different populations may perform differently under competition, the low rates of inbreeding indicate that this may not be a significant source of error. The two islands have higher levels of inbreeding (Table 5) but, as all individuals appear to suffer almost complete suppression the effect of differential survival of estimates of $\mathrm{F}_{\mathrm{ST}}$ may also be minimal or non-existent.
Another related issue is that, in general, quantitative data appears to be collected at only one location (see review by MERILÄ and CRNOKRAK, 2001), as it was in the current study. Therefore the $\mathrm{Q}_{\mathrm{ST}}$ data should be considered site specific. Yet, previously published results from provenance trials in $P$. radiata across a wide range of sites (see RAYMOND and HENSON, 2009) indicate genotype by environment interaction can be present for growth traits, with Año Nuevo being the most interactive provenance. The island provenances are always the poorest for height or diameter and Monterey is generally the best and Año Nuevo grows well on high growth sites but very poorly on low growth sites in NSW (JoHNSON et al., 1997) and New Zealand (BuRdon et al., 1997, 1998). So, while providing some evidence that selection has driven differentiation between provenances in radiata pine, this study also raises significant issues that affect both the interpretation of these data and the design of any future studies. These include questions such as - What effect would this genotype by environment interaction have on the perceived genetic structure of the species? Could genotype by environment interactions be so large as to alter the ranking of the mainland provenances or only be sufficient to affect the strength of the inter-connections? Would estimating $\mathrm{Q}_{\mathrm{ST}}$ over a number of sites act as a form of sensitivity analysis for the structure? Unfortunately these ideas can not be tested for $P$. radia$t a$ as none of the other existing provenance trials have individual family structure maintained.

\section{Acknowledgments}

These provenance/progeny trials were established in collaboration with CSIRO Division of Forest Research. The authors would like to thank IAN JOHNSON, DPI NSW, Beecroft who was responsible for the pine breeding program at this time. For the Green Hills trial, CSIRO measured height and diameter at age 3 and the age 8 measurements were done by Forests NSW and CSIRO collaboratively. The authors with to thank Forests NSW field staff in Tumut for undertaking the age 24 and 26 assessment and especially thank KEVIN DoDDs for organizing the assessments, sorting out the maps and cleaning up the data. The 2006 assessment were funded by the Radiata Pine Breeding Company, Rotorua, New Zealand.

\section{References}

Ades, P. K. and J. A. Simpson (1991): Variation in susceptibility to Dothistroma needle blight among provenances of Pinus radiata var. radiata. Silvae Genetica 40: 6-13.

Burdon, R. D. (1992): Genetic survey of Pinus radiata. 9: General discussion and implications for genetic management. New Zealand Journal of Forestry Science 22: 274-298.

Burdon, R. D. and C. B. Low (1992): Genetic survey of Pinus radiata. 6: wood properties: variation, heritabilities, and interrelationships with other traits. New Zealand Journal of Forestry Science 22: 228-245.

Burdon, R. D., M. H. Bannister, H. A. I. Madgwick and C. B. Low (1992): Genetic survey of Pinus radiata. 1: introduction, description of experiment, and basic methodology. New Zealand Journal of Forestry Science 22: 119-137.

Burdon, R. D., R. E. Gaskin, J. A. ZaBkiewiCz and C. B. Low (1992): Genetic survey of Pinus radiata. 7: variation and 
Table 5. - Mean number of alleles (A), expected heterozygosity $\left(\mathrm{H}_{\mathrm{e}}\right)$, differentiation of individual provenances from the common gene pool $\left(\Theta_{\mathrm{p}}\right)$ and inbreeding coefficient for each provenance (from MORAN et al., 1988; KARHU et al., 2006 and VoGL et al., 2002).

\begin{tabular}{|l|c|c|r|c|c|c|}
\hline & \multicolumn{2}{|c|}{ Isozymes } & \multicolumn{3}{c|}{ Microsatellites } & Inbreeding \\
\hline Provenance & $\mathrm{A}$ & \multicolumn{1}{c|}{$\mathrm{H}_{\mathrm{e}}$} & \multicolumn{1}{c|}{$\mathrm{A}$} & $\mathrm{H}_{\mathrm{e}}$ & $\Theta_{\mathrm{p}}$ & coefficient \\
\hline Año Nuevo & 1.47 & 0.088 & 8.42 & 0.76 & 0.0625 & 0.04 \\
Monterey & 1.74 & 0.097 & 10.00 & 0.77 & 0.0156 & 0.04 \\
Cambria & 1.58 & 0.110 & 8.47 & 0.77 & 0.0443 & 0.03 \\
Guadalupe & 1.56 & 0.092 & 7.32 & 0.69 & 0.1516 & 0.09 \\
Cedros & 1.46 & 0.089 & 6.73 & 0.68 & 0.1803 & 0.13 \\
\hline
\end{tabular}

inheritance of pinene composition in wood oleoresin. New Zealand Journal of Forestry Science 22: 246-256.

Burdon, R. D., A. FirTh, C. B. Low and M. A. Miller (1997): Native provenances of Pinus radiata in New Zealand: performance and potential. New Zealand Forestry 41: 32-36.

Burdon, R. D., A. FirTh, C. B. Low and M. A. Miller (1998): Multi-site provenance trials of Pinus radiata in New Zealand. Forest Genetic Resources 26: 3-8.

Butcher, T. B. and M. J. C. Stukely (1997): Variation in natural populations of Pinus radiata in resistance to Phytopthora cinnamomi. IUFRO '97 Genetics of Radiata Pine, Rotorua, New Zealand, New Zealand Forest Research institute.

ELDRIDGE, K. G. (1978): Refreshing the genetic resources of radiata pine plantations. CSIRO Division of Forest Research, Genetics Section Report, No. 7, 120 pp.

GaRnier-GÉRÉ, P.-H., A. C. Matheson and P. K. AdEs (1997): Assessment of the genetic potential for adaptation of natural provenances: case study of Pinus radiata. IUFRO'97 Genetics of radiata pine, Rotorua, New Zealand, FRI Bulletin.

Gilmour, A. R., B. J. Gogel, B. R. Cullis, S. J. Welham and R. Thompson (2002): ASReml user guide release 1. VSN, Hemel Hempstead, UK.

Johnson, I. G., P. K. AdEs and K. G. EldRIDGe (1997): Growth of natural Californian provenances of Pinus radiata in New South Wales, Australia. New Zealand Journal of Forestry Science 27: 23-38.

Karhu, A., C. Vogl, G. F. Moran, J. C. Bell and O. SAVOLAINEN (2006): Analysis of microsatellite variation in Pinus radiata reveals effects of genetic drift but no $\underline{\text { recent bottlenecks. Journal of Evolutionary }} \frac{\text { Biology }}{19}$ 167-175.

KINLOCH, B. B. and W. J. LIBBY (1997): Variation in susceptibility to Western gall rust in Pinus radiata and $P$. muricata. IUFRO '97 Genetics of Radiata Pine, Rotorua, New Zealand, New Zealand Forest Research institute.

LATTA, R. G. (2003): Gene flow, adaptive population divergence and comparative population structure across loci. New Phytologist 161: 51-58.

LIBBY, W. J. (1997): Native origins of domesticated radiata pine. In: Burdon, R. D. and Moore, J. M. IUFRO '97 Genetics of Radiata Pine. FRI Bulletin No. 203. Rotorua New Zealand. pp. 9-25.

McKAY, J. K. and R. G. LATTA (2002): Adaptive population divergence: markers, QTL and traits. Trends in Ecology and Evolution 17: 285-291.

MERILÄ, J. and P. CRNOKRAK (2001): Comparison of genetic differentiation at marker loci and quantitative traits. Journal Evolutionary Biology 14: $\frac{19}{892}-903$.

MillaR, C. I. (1986): The Californian closed cone pines (Subsection Oocarpae Little and Critchfield) - a taxonomic history and review. Taxon 35: 657-670.

MillaR, C. I. (1997): Quaternary evolution of Pinus radiata. IUFRO '97 Genetics of Radiata Pine, Rotorua New Zealand, New Zealand Forest Research Institute.
Miller, J. D., B. P. Wood and M. B. Hamilton (2008): $\mathrm{F}_{\mathrm{st}}$ and $\mathrm{Q}_{\text {st }}$ under neutrality. Genetics 180: 1023-1037.

Moran, G. F., J. C. Bell and K. G. EldRIDGe (1988): The genetic structure and the conservation of the five natural populations of Pinus radiata. Canadian Journal of Forest Research 18: 506-514.

Moran, G. F. and J. C. BeLl (1987): The origin and genetic diversity of Pinus radiata in Australia. Theoretical and Applied Genetics 43: 616-622.

Pritchard, J. K., M. Stephens and P. Donnelly (2000): Inference of population structure using multilocus genotype data. Genetics 155: 945-959.

PRITChaRd, J., D. FALUSH and M. StEPhENS (2002): Inference of population structure in recently admixed populations. American Journal of Human Genetics 71: 177-177.

RAYMOND, C. A. and M. Henson (2009): Genetic variation within the native provenances of Pinus radiata D. Don. 1. Growth and form to age 26 years. Silvae Genetica 58: 242-252.

RAYmond, C. A., M. Henson and B. JoE (2009): Genetic variation within the native provenances of Pinus radiata D. Don. 2. Wood density and stiffness at age 26 years. Silvae Genetica, 58: 192-204.

Rogers, D. L. (2002): In situ Genetic Conservation of Monterey pine (Pinus radiata D. Don): Information and Recommendations. University of California, Division of Agriculture and Natural Resources, Genetic Conservation Program Report No. 26. Davis, California, USA.

RosenBerG, N. A. (2005): Algorithms for selecting informative marker panels for population assignment. Journal of Computational Biology 12: 1183-1201.

Rosenberg, N. A., T. Burke, K. Elo, M. W. Feldmann, P. J. Freidlin, M. A. M. Groenen, J. Hillel, A. Maki-Tanila, M. Tixier-Boichard, A. Vignal, K. Wimmers and S. WEIGEND (2001): Empirical evaluation of genetic clustering methods using multilocus genotypes from 20 chicken breeds. Genetics 159: 699-713.

Rosenberg, N. A., L. Li, R. Ward and J. K. Pritchard (2003): Informativeness of genetic markers for inference of ancestry. American Journal of Human Genetics 73: 1402-1422.

Rosenberg, N. A., S. Mahajan, S. Ramachandran, C. F. ZhaO, J. K. PRITChaRd and M. W. Feldman (2005): Clines, clusters, and the effect of study design on the inference of human population structure. Plos Genetics 1: 660-671.

Steane, D. A., N. Conod, R. C. Jones, R. E. Vaillancourt, B. M. PотTs (2006): A comparative analysis of population structure of a forest tree, Eucalyptus globulus (Myrtaceae), using microsatellite markers and quantitative traits. Tree Genetics \& Genomes 2: 30-38.

Vogl, C., A. Karhu, G. Moran and O. SAVolainen (2002): High resolution analysis of mating systems: inbreeding in natural populations of Pinus radiata. Journal of Evolutionary Biology 15: 433-439. 